Manuscript received 25.02.2020

Accepted: 09.04.2020

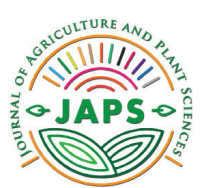

In print: ISSN 2545-4447

On line: ISSN 2545-4455

doi: https://doi.org/10.46763/JAPS2010031k

Original scientific paper

\title{
OBSERVATION OF GRAPEVINE PHYTOPLASMAS STATUS (CANDIDATUS PHYTOPLASMA SOLANI) IN THE REPUBLIC OF NORTH MACEDONIA
}

\author{
Vasil Kostadinovski ${ }^{1}$, Emilija Arsov ${ }^{2}$, Sasa Mitrev ${ }^{2}$ \\ ${ }^{1}$ Goce Delcev University - Stip, Faculty of Agriculture, Republic of North Macedonia, \\ Agronomy engineer \\ ${ }^{2}$ Goce Delcev University - Stip, Faculty of Agriculture, \\ Department for Plant and Environmental protection, UNILAB laboratory, \\ Republic of North Macedonia \\ *Corresponding author:emilija.arsov@ugd.edu.mk
}

\begin{abstract}
Phytoplasmas ("Candidatus Phytoplasma") are non-cultivable wall-less bacteria found in plant phloem and insect vector cells. Economically important Grapevine yellows (GY) diseases all over the world are caused by phytoplasmas belonging to the ribosomal subgroups $16 \mathrm{SrV}-\mathrm{C}$ and $-\mathrm{D}$ (etiological agents of Flavescence dorée, FD) and 16SrXII-A ("Candidatus Phytoplasma solani", etiological agents of Bois noir, BN) which cause similar symptoms but in epidemiology considerably different.

The aim of this study was to identify and characterize the phytoplasmas associated with GY in vineyards in our country, through the molecular analysis of the genes stamp and map. The obtained results showed the presence of BN Bois noir, stolbur, economic important phytoplasma that cause serious losses on grapes. In detail, molecular characterization evidenced that BN phytoplasma strains belong to three distinct stamp genotypes (St1, St30, St37), while FD phytoplasma is not present in our country yet.

This data will be helpful for further analysis focused on investigating the epidemiology of BN and FD.
\end{abstract}

Key words: grapevine yellows, Flavescence doree, Bois Noir, stamp and map genes

\section{INTRODUCTION}

Grapevine yellows (GY), a group of diseases that were originally thought to be caused by viruses, are now known to have a phytoplasma etiology. The first disorder reported from Vitis vinifera, and the most widely known of the GY group, is certainly Flavescence dorée (FD), which appeared in South-West France in the 1950's, where from it spread to other viticultural districts of France, Northern Italy and neighbouring European countries. Bois noir (BN), which symptoms are indistinguishable from those of FD, was also firstly reported from France, then from the most important viticultural areas of Europe, including Italy (Belli et al., 2010).

Phytoplasmas are plant pathogenic bacteria in the class Mollicutes and were formerly called "mycoplasma - like organisms" (MLOs) (Doi et al., 1967). They are transmitted by insect vectors (leafhoppers and psyllids) and infect hundreds of plant species worldwide, including many economically important crops, fruit trees, and ornamental plants (Hogenhout et al., 2008; Oshima et al., 2013). More than 700 plant species are affected by phytoplasma diseases and many of them show symptoms such as yellowing, witches broom (proliferating shoots), phyllody (leaf-like petals and sepals), virescence (greening of floral organs), and sometimes withering of plants (Lee et al., 2000).

Phytoplasmal diseases are the primary factors limiting production of many important crops all over the world: since the risk to introduce these diseases by the movement of phytoplasma infected plants (mainly propagating material) precise and strict quarantine regulations are applied in all over the world.

The presence of BN phytoplasmas in North 
Macedonia was reported for the first time in 2003 , in a survey limited to a small viticultural region, i.e. Veles and Skopje areas (Šeruga et al., 2003).

The affected vines show downward rolling of the leaves accompanied by yellow or bright red discoloration of veins and blades, berry withering and uneven or total lack of cane lignification. GY, however, have different phytoplasma species as causal agent, as well as different insect vectors, which are either leafhoppers or planthoppers (Homoptera: Auchenorrhyncha) that feed either specifically or occasionally on the vines. (Belli et al., 2010). It seems, that the relationship between diseases and insect vectors is subject that needs to be more deeply investigated for a better understanding of GY epidemiology and for the hopeful development of new sustainable means for their containment. Damages caused by GY may be extensive and economically relevant, since the most of the diseased vines are lost.

The cycle of transmission of phytoplasmas depends on the life cycle (monovoltine, multivoltine) and feeding habit (monophagous, polyphagous) of their insects vectors, polyphagous vectors have the potential to inoculate a wide range of plant species, depending on the resistance to infection of each host plant. (Bosco et al., 1997).

The transmission process consists of three steps, acquisition, latent period, and inoculation. Vectors acquire phytoplasmas by feeding on infected plants for some hours/ days and become inoculative after a latent period of two or more weeks during which the microorganisms multiply in their organs and hemolymph. A method to reduce alternative vector host plants of phytoplasma-infected crop plants and weeds is by roguing. The most effective means of insect vector control is through physical prevention - either by use of screening or by use of a mineral coating on the plant itself.

The primary means of controlling phytoplasma vectors is by insecticides; however, increasing pressure to find less toxic and more biologically based techniques to control, or at least manage, insect vectors necessitates an even greater reliance on solid understandings of the biology of insect vectors from the cellular to the ecological level. (Conti \& Alma, 2002).

The activities carried out in this paper were laboratory analyses conducted on Vranec variety in Peshirovo locality (N. Macedonia).

\section{MATERIAL AND METHODS}

GY monitoring and sample collection in vineyards

In order to determine the GY associated phytoplasmas (check status of BN and FD phytoplasmas) in the examined vine regions, leaf samples of symptomatic grapevines (Vitis vinifera L.) were collected in September

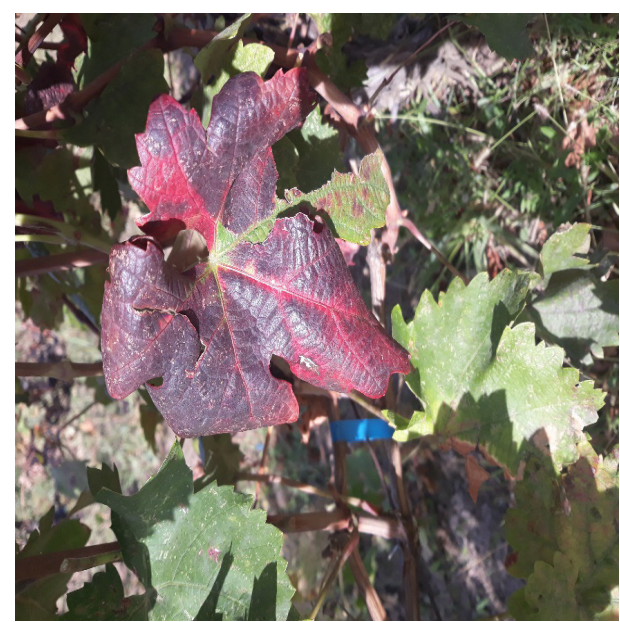

and October 2018 in N. Macedonia (Figure 1 a. and b.). In details, leaf samples were collected from several symptomatic plants from the variety Vranec in Peshirovo (Ovce Pole, N. Macedonia) (Table 1).

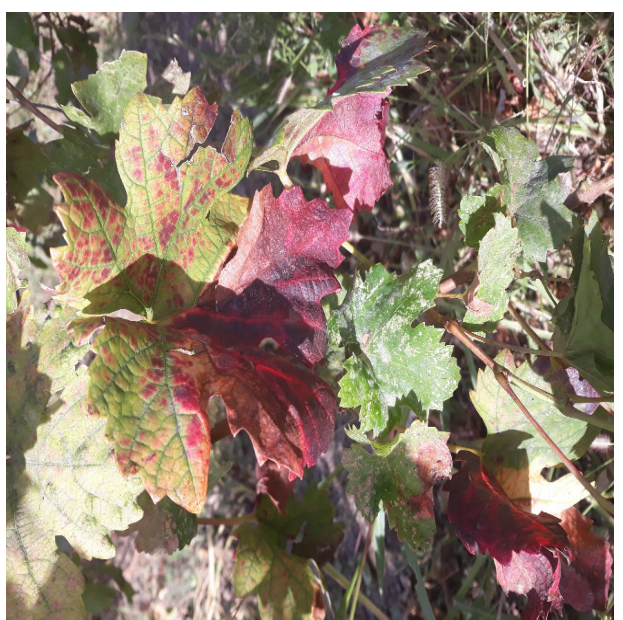

Figure 1. Collected plant samples from vineyards in Peshirovo, Ovce Pole, N. Macedonia

- Typical symptoms on leaves (triangle form, reddening);

- Mix infection of symptomatology (red spots on leaves and reddening - virus and phytoplasmas symptoms) 
Table 1. Selected grapevine leaves samples from Peshirovo, North Macedonia for laboratory analyses.

\begin{tabular}{|c|c|c|}
\hline Location & Variety & Lab code of plant samples \\
\hline \multirow{3}{*}{ Pesirovo, Sv. Nikole } & \multirow{3}{*}{ Vranec, local red variety } & BN34 \\
\cline { 3 - 3 } & & BN35 \\
\cline { 3 - 3 } & & BN36 \\
& & BN37 \\
\hline
\end{tabular}

\section{Laboratory analysis}

Leaf samples collected in vineyards were stored at $-20^{\circ} \mathrm{C}$, for the following molecular analyses: (i) total nucleic acid extraction; (ii) identification of phytoplasmas by amplification of the genes stamp (BN) and map (FD); (iii) molecular characterization of phytoplasmas through analysis of nucleotide sequences of the genes stamp and map.

\section{Extraction of total nucleic acids}

Total nucleic acids (TNA) were extracted from $1 \mathrm{~g}$ of plant material using a modification of the cethyltrimethyl-ammonium bromide (CTAB) procedure described by Angelini et al. (2001). Nucleic acids were diluted in sterile deionised water to a final concentration of $20 \mathrm{ng} / \mu \mathrm{l}$.

\section{Analysis of Nanodrop-Spectrophotometry}

The NanoDrop is a spectrophotometer that allows us to quantify nucleic acids from different samples, using micro-volumes and freeing itself from the use of the classic cuvettes. It is composed of an instrumental part and software installed in a computer (Figure 2).

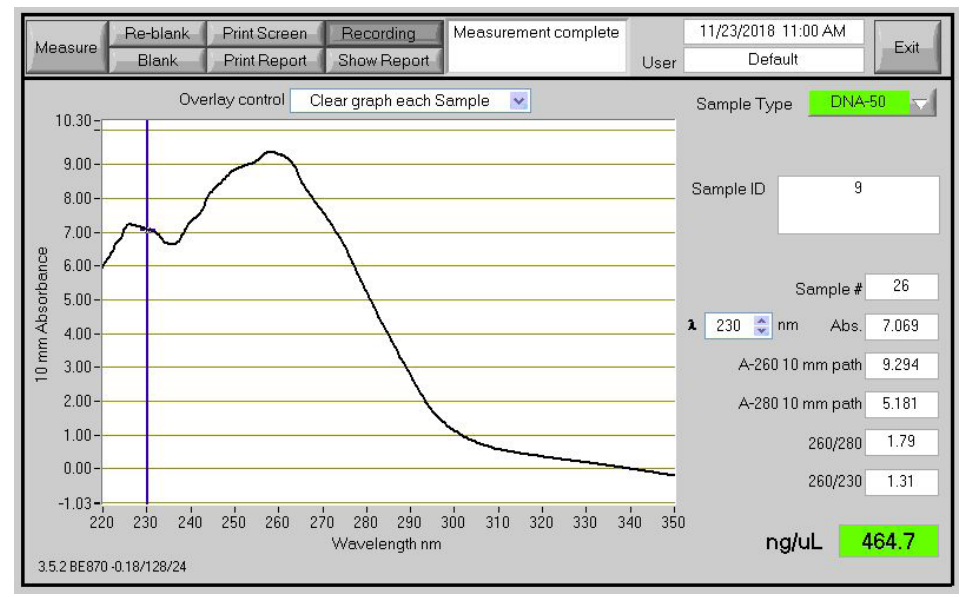

Figure 2. Example of DNA analysis by Nanodrop-spectrophotometer.

\section{Molecular Identification - Polimerase chain reaction PCR}

The molecular detection of BN phytoplasma was carried out on the stamp gene (coding the antigenic protein of ' $\mathrm{Ca}$. $\mathrm{P}$. solani' membrane). Stamp gene was amplified by nested-PCR using primer pairs: Stamp-F (5'-GTAGGTITGGATGTITTAAG-3') / Stamp-RO (5'-AAATAAAAGAACAAGTATAGACGA-3'), followed by primers Stamp-F1 (5'-TTCTTTAAACACACCAAGAC-3') / Stamp-R1 (5'- AAGCCAGAATTTAATCTAGC-3') (Fabre et al., 2011). The reaction conditions were as follows: (i) $\mathrm{dPCR}: 94^{\circ} \mathrm{C} \times 4 \mathrm{~min} ; 35$ cycles consisting in: $94^{\circ} \mathrm{C} \times 30 \mathrm{~s}, 56^{\circ} \mathrm{C} \times 30 \mathrm{~s}$ and $72^{\circ} \mathrm{C}$ $x 1 \mathrm{~min} 30 \mathrm{~s}$; final extension at $72{ }^{\circ} \mathrm{C} \times 7 \mathrm{~min}$; (ii) nested-PCR: $94^{\circ} \mathrm{C} \times 4$ min; 35 cycles consisting in: $94^{\circ} \mathrm{C} \times 30 \mathrm{~s}, 52^{\circ} \mathrm{C} \times 30 \mathrm{~s}$ and $72^{\circ} \mathrm{C} \times 30 \mathrm{~s}$; final extension at $72{ }^{\circ} \mathrm{C} \times 7 \mathrm{~min}$.

The PCR mix was as follows: Taq $0.125 \mathrm{U} /$ $\mu$ l; Buffer $1 \mathrm{X} ; \mathrm{MgCl}_{2} 1.5 \mathrm{mM}$, Forward example $0.4 \mu \mathrm{M}$, Reverse example $0.4 \mu \mathrm{M}$, dNTPs $0.2 \mu \mathrm{M}$.

All PCR products were analysed by electrophoresis in 1\% agarose gel and stained with Midori Green. Electrophoresis was performed using $100 \mathrm{~V}$ for 30 minutes. DNA was visualized under UV light on a transilluminator.

The molecular detection of FD phytoplasma was carried out on the map gene (coding methionine aminopeptidase). Plant total nucleic acids were employed as templates in nested PCR 
assays performed using primer pair: FD9f5 (5'CAAAAAATTACTTTTGGCGGGAC-3') and MAPr1 (5'-TGCTCAAAATGAGCGCTTAAAC-3'), followed by FD9f6 (5'-GTCGCTTTAGAATCGACACA-3') and MAPr2 (5'-TCGGAAGTAACAGCAGTCCA-3'). Direct and nested PCR conditions were: $1 \mathrm{~min}$ at $92^{\circ} \mathrm{C}$ and 35 cycles, with 1 cycle consisting

\section{Nucleotide sequence analysis}

The PCR products of stamp and map genes, amplified by vine plants, were sequenced at a commercial service (Eurofins Genomics, Germany) with a minimum coverage of $3 X$. The obtained nucleotide sequences, whose quality has been evaluated through electropherogram analysis, have been assembled with the CAP (Contig Assembly Program) function of the BioEdit software, version 7.2.5 (Hall, 1999). In order to characterize the phytoplasma strains, the nucleotide sequences of the stamp and map genes were inserted into a database containing the sequences of the representative strains of the stamp gene variants of ' $\mathrm{Ca}$. P. solani' and the map gene variants of phytoplasmas associated of $30 \mathrm{~s}$ at $92^{\circ} \mathrm{C}, 30 \mathrm{~s}$ at $52^{\circ} \mathrm{C}$, and $1 \mathrm{~min} 30 \mathrm{~s}$ at $66^{\circ} \mathrm{C}$ (Arnaud et al., 2007). The PCR mix was as follows: Taq $0.125 \mathrm{U} / \mathrm{ml}$; Buffer $1 \mathrm{X} ; \mathrm{MgCl}_{2} 1.5$ $\mathrm{mM}$, Forward primer $\quad 0.4 \mathrm{mM}$, Reverse primer $0.4 \mathrm{mM}$, dNTPs $0.2 \mathrm{mM}$. All PCR products were analyzed by electrophoresis in $1 \%$ agarose gel and stained with Midori Green.

with FD, available in GenBank (Quaglino et al., 2016; Casati et al., 2017)

The sequences have been aligned through the "ClustalW Multiple Alignment" function of the Bioedit software. The alignments obtained were used to calculate the sequence identity with the "Sequence identity Matrix" function. Based on the sequence identity of the stamp and map genes the phytoplasmas were inserted into gene variants already known or proposed for the first time in this work. In addition, the alignments were used for the subsequent phylogenetic analysis conducted with the MEGA6 software (Tamura et al., 2013), using the 'neighbour-joining' algorithm (bootstrap 1000).

\section{RESULTS AND DISCUSSION}

Identification of GY phytoplasmas

PCR amplification showed that: (i) three (BN34, BN36, BN38) out of five Vranec plants from
Macedonia were infected by BN phytoplasma, and FD phytoplasma was not detected in tested samples (Figure 3).

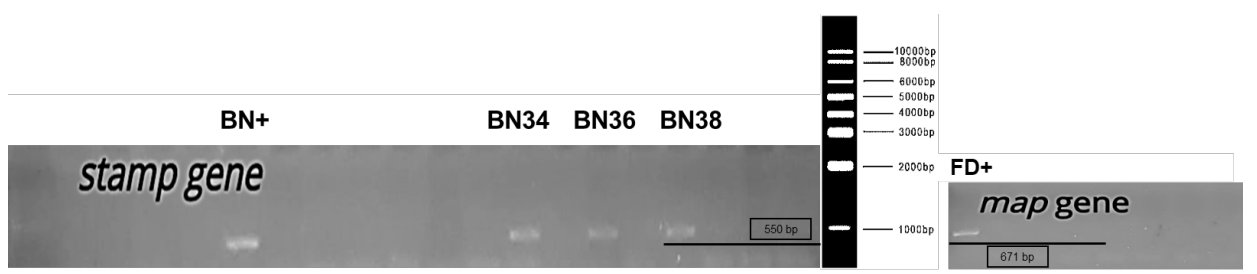

Figure 3. Visualization of PCR products obtained through the amplification of stamp and map genes.

Table 3. BN and FD phytoplasma identification in grapevines.

\begin{tabular}{|c|c|c|c|c|c|}
\hline \multirow[b]{2}{*}{ Locality } & \multirow[b]{2}{*}{ Variety } & \multirow[b]{2}{*}{ Sample } & \multirow{2}{*}{$\begin{array}{c}\text { Date of } \\
\text { sampling }\end{array}$} & \multicolumn{2}{|c|}{ PCR } \\
\hline & & & & stamp (BN) & $\operatorname{map}(F D)$ \\
\hline \multirow{5}{*}{ Peshirovo, Ovce Pole } & \multirow{5}{*}{ Vranec } & BN34 & IX.2018 & + & - \\
\hline & & BN35 & IX.2018 & - & - \\
\hline & & BN36 & IX.2018 & + & - \\
\hline & & BN37 & IX.2018 & - & - \\
\hline & & BN38 & IX.2018 & + & - \\
\hline
\end{tabular}


Molecular characterization

Analysis of the gene stamp

Sequence identity analysis of stamp gene nucleotide sequences showed that BN phytoplasma strains identified in grapevine BN34, BN36 and BN38 are characterized by distinct stamp gene variants. In detail, strains identified in plants BN34 and BN38 have stamp variants undistinguishable from the variants St1 and St30, respectively. The strain infecting the plant BN36 showed best identity with sequence variants St4, St15 and St37 (Table 4, 5).

Table 4. Sequence identity matrix of the stamp gene. Comparison between the gene variants was found. The identical gene variants are indicated by the same colour.

\begin{tabular}{|c|c|c|c|c|c|c|c|c|c|c|c|c|c|c|c|c|}
\hline & Seq-> & 1 & 2 & 3 & 4 & 5 & 6 & 7 & 8 & 18 & 19 & 32 & 33 & 34 & 39 & 40 \\
\hline 1 & BN34 & ID & 0.964 & 0.997 & 1 & 0.987 & 0.952 & 0.962 & 0.979 & 0.962 & 0.956 & 0.927 & 0.997 & 0.985 & 0.952 & 0.964 \\
\hline 2 & BN36 & 0.964 & ID & 0.966 & 0.964 & 0.976 & 0.987 & 0.995 & 0.968 & 0.995 & 0.978 & 0.946 & 0.966 & 0.978 & 0.985 & 0.995 \\
\hline 3 & BN38 & 0.997 & 0.966 & ID & 0.997 & 0.985 & 0.954 & 0.964 & 0.977 & 0.964 & 0.954 & 0.925 & 1 & 0.983 & 0.954 & 0.966 \\
\hline 4 & Rqg50_(KC703019)_St1 & 1 & 0.964 & 0.997 & ID & 0.987 & 0.952 & 0.962 & 0.979 & 0.962 & 0.956 & 0.927 & 0.997 & 0.985 & 0.952 & 0.964 \\
\hline 5 & Rqg31_(KC703017)_St2 & 0.987 & 0.976 & 0.985 & 0.987 & ID & 0.964 & 0.974 & 0.991 & 0.974 & 0.968 & 0.938 & 0.985 & 0.997 & 0.964 & 0.976 \\
\hline 6 & Rpm35_(KC703015)_St3 & 0.952 & 0.987 & 0.954 & 0.952 & 0.964 & ID & 0.983 & 0.955 & 0.983 & 0.974 & 0.938 & 0.954 & 0.966 & 0.985 & 0.983 \\
\hline 7 & STOL_(FN813261)_St4 & 0.962 & 0.995 & 0.964 & 0.962 & 0.974 & 0.983 & ID & 0.966 & 0.995 & 0.978 & 0.944 & 0.964 & 0.976 & 0.981 & 0.991 \\
\hline 8 & GGY_(FN813256)_St5 & 0.979 & 0.968 & 0.977 & 0.979 & 0.991 & 0.955 & 0.966 & ID & 0.97 & 0.964 & 0.942 & 0.977 & 0.989 & 0.955 & 0.972 \\
\hline 18 & P7_(FN813258)_St15 & 0.962 & 0.995 & 0.964 & 0.962 & 0.974 & 0.983 & 0.995 & 0.97 & ID & 0.974 & 0.948 & 0.964 & 0.976 & 0.981 & 0.995 \\
\hline 19 & L973_(FN813255)_St16 & 0.956 & 0.978 & 0.954 & 0.956 & 0.968 & 0.974 & 0.978 & 0.964 & 0.974 & ID & 0.942 & 0.954 & 0.968 & 0.976 & 0.974 \\
\hline 32 & Vv12_274_(KJ469717)_St29 & 0.927 & 0.946 & 0.925 & 0.927 & 0.938 & 0.938 & 0.944 & 0.942 & 0.948 & 0.942 & ID & 0.925 & 0.936 & 0.934 & 0.946 \\
\hline 33 & Vv24_(KC703022)_St30 & 0.997 & 0.966 & 1 & 0.997 & 0.985 & 0.954 & 0.964 & 0.977 & 0.964 & 0.954 & 0.925 & ID & 0.983 & 0.954 & 0.966 \\
\hline 34 & Rqg42_(KC703016)_St31 & 0.985 & 0.978 & 0.983 & 0.985 & 0.997 & 0.966 & 0.976 & 0.989 & 0.976 & 0.968 & 0.936 & 0.983 & ID & 0.964 & 0.978 \\
\hline 39 & Carv2_(KT184880)_St36 & 0.952 & 0.985 & 0.954 & 0.952 & 0.964 & 0.985 & 0.981 & 0.955 & 0.981 & 0.976 & 0.934 & 0.954 & 0.964 & ID & 0.981 \\
\hline 40 & Char7_(KT184881)_St37 & 0.964 & 0.995 & 0.966 & 0.964 & 0.976 & 0.983 & 0.991 & 0.972 & 0.995 & 0.974 & 0.946 & 0.966 & 0.978 & 0.981 & ID \\
\hline
\end{tabular}

Table 5. Stamp and map sequence variants identified in BN and FD phytoplasma strains identified in this study.

\begin{tabular}{|c|c|c|c|c|c|}
\hline & & \multicolumn{2}{|c|}{ PCR } & \multicolumn{2}{|c|}{ Variety of sequence } \\
\hline & samples & stamp & map & stamp & map \\
\hline \multirow{5}{*}{ 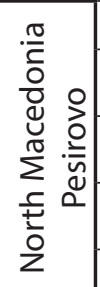 } & BN34 & + & - & St1 & - \\
\hline & BN35 & - & - & - & - \\
\hline & BN36 & + & - & St4, St15, St37 & - \\
\hline & BN37 & - & - & - & - \\
\hline & BN38 & + & - & St30 & - \\
\hline
\end{tabular}

\section{Phylogenetic analysis}

Phylogenetic analysis of stamp gene alignment showed the presence of four main clusters: cluster a, related to nettle epidemiology (nettle-related), and clusters b-I, b-II and b-III, related to bindweed epidemiology (bindweedrelated). The BN phytoplasma strains identified in Vranec variety from North Macedonia grouped in the clusters b-II and b-III (Figure 4). 


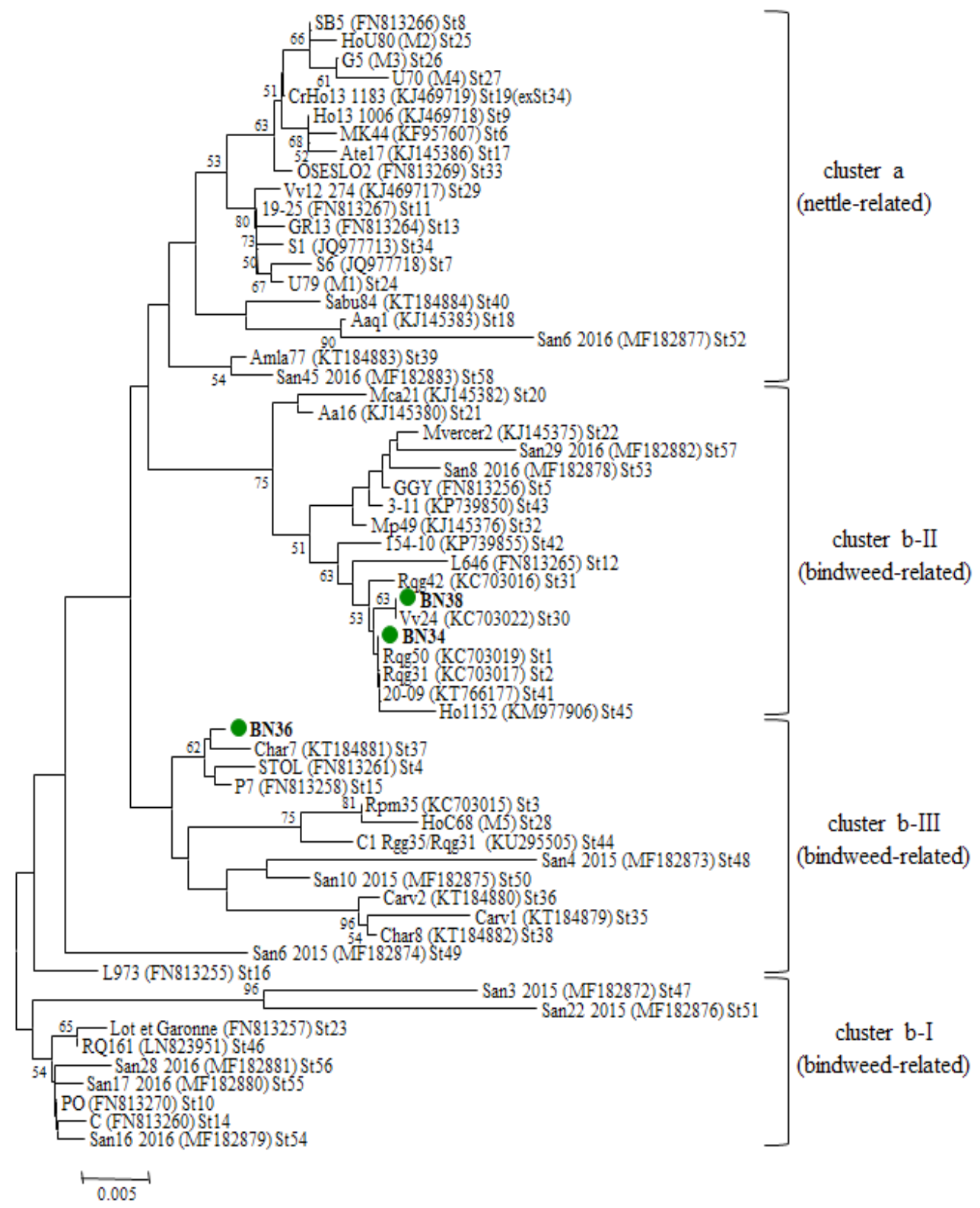

Figure 4. Phylogenetic tree built on the basis of the nucleotide sequences of the stamp gene.

\section{CONCLUSION}

The results obtained in this thesis have confirmed the prevalence of ' $\mathrm{C}$. P. Polani', the etiological agent of $\mathrm{BN}$, in N. Macedonia (Kostadinovska et al., 2014), and the absence of FD. This evidence could suggest that such varieties could be less susceptible to phytoplasmas associated with GY.

Molecular characterization by the analysis of stamp gene nucleotide sequences showed the presence of distinct variants (St1, St30, St37) among BN phytoplasmas identified in North Macedonia. These variants were largely identified, in previous studies, in Macedonia,
Serbia, Croatia and Georgia (Mitrev et al., 2008, Cvrkovic et al., 2014; Kostadinovska et al., 2014; Quaglino et al., 2016). BN epidemiology involves a broad range of plant hosts and insect vectors (Marcone et al., 1997; Schneider et al., 1997; Mori et al., 2015).

This study, for the first time observed a complete laboratory analyzes for $\mathrm{BN}$ and FD phytoplasmas, including molecular identification, nucleotide sequence analysis and phylogenetic analyzes which group BN phytoplasma in clusters b-II and b-III. 


\section{LITERATURE}

Angelini, E., Clair, D., Borgo, M., Bertaccini, A., Boudon-Padieu, E. (2001). Flavescence dorée in France and Italy - Occurrence of closely related phytoplasma isolates and their near relationships to Palatinate grapevine yellows and an alder yellows phytoplasma. Vitis, 40: 7986.

Belli, G., Bianco, P.A. and Conti, M. (2010). Grapevine yellows in Italy: past, present and future. Journal of Plant Pathology, 92 (2), 301324.

Bosco, D., Minucci, C., Boccardo, G., Conti, M., (1997). Differential acquisition of chrysanthemum yellows phytoplasma by three leafhopper species. Entomologia Experimentalis et Applicata, 83, 219-24.

Casati, P., Quaglino, F., Murolo, S., Wei Wei, Bianco, P. A., Durante, G, Davis, E.R, Zhao, Y. (2017). Identification of new -J and -K 16SrXII subgroups and distinct single nucleotide polymorphism genetic lineages among 'Candidatus Phytoplasma solani' strains associated with bois noir in Central Italy. Australasian Plant Pathology, 46 (1): 31-34.

Conti, M., Alma, A. (2002). Fitoplasmi e insetti vettori. Petria, 12: 353-359.

Cvrkovic, T., Jovic, J., Mitrovic, M., Krstic, O., and Tosevski, I. (2014). Experimental and molecular evidence of Reptalus panzeri as a natural vector of Bois noir. Plant Pathol,. 63:4253.

Doi, Y., Teranaka, M, Yora, K., Asuyama H. (1967). Mycoplasma or PLT group-like microorganisms found in the phloem elements of plants infected with mulberry dwarf, potato witches' broom, aster yellows or paulownia witches' broom (in Japanese with English summary). Ann Phytopath Soc Japan, 33:259266.

Hall, Tomas, A., (1999). BioEdit: a userfriendly biological sequence alignment editor and analysis program for Windows 95/98/NT. Nucleic Acids Symposium Series No., 41 95-98.

Hogenhout, S.A., Oshima, K., Ammar, E-D, Kakizawa, S., Kingdom, H.N., Namba, S. (2008). Phytoplasmas: bacteria that manipulate plants and insects. Mol Plant Pathol, 9:403-423.
Kostadinovska, E., Quaglino, F., Mitrev, S., Casati, P., Bulgari, D., Bianco, P.A. (2014). Multiple gene analyses identify distinct "Bois noir" phytoplasma genotypes in the Republic of Macedonia. Phytopathologia Mediterranea, 491-501.

Lee, I.M., Davis, R.E., Gundersen-Rindal, D.E. (2000). Phytoplasma: phytopathogenic mollicutes. Annual Review of Microbiology, 54: 221-255.

Marcone, C., Ragozzino, A., Seemuller, E. (1997). Detection and identification of phytoplasmas infecting vegetable, ornamental and forage crops in Southern Italy. Journal of Plant Pathology, 79: 211-7.

Mitrev, S., Spasenoski, M., Arsov, E. (2008). Molecular Detection and Characterization of Grapevine Phytoplasmas in Macedonia. Yearbook of Faculty of Agriculture, 8(1), 7-17.

Mori, N., Quaglino, F., Tessari, F., Pozzebon, A., Bulgari, D., Casati, P., and Bianco, P. A. (2015). Investigation on 'Bois noir' epidemiology in north-eastern Italian vineyards through a multidisciplinary approach. Ann. Appl. Biol., 166:75-89.

Oshima, K., Maejima, K., Namba, S. (2013). Genomic and evolutionary aspects of phytoplasmas. Front Microbiol, 4:230

Quaglino, F., Chkhaidze, N., Casati, P., Maghradze, D., Failla, O., Bianco, P.A. (2016). New 'Candidatus Phytoplasma solani' strains associated with Bois noir disease in Vitis vinifera L. cultivars in Georgia.- Mitteilungen Klosterneuburg 66:50-54

Schneider, B., Gibb, K.S., Seemuller, E. (1997). Sequence and RFLP analysis of the elongation factor Tu gene used in differentiation and classification of phytoplasmas. Microbiology, 143: 3381-9.

Tamura, K., Stecher, G., Peterson, D., Filipski, A., Kumar, S. (2013). MEGA6 Molecular Evolutionary Genetics Analysis Version 6.0. Mol Biol Evol.; 30(12): 2725-2729

Šeruga, M., Škorič, D., Kozina, B., Mitrev, S., Krajačič, M., Curkovič, P. (2003). Molecular identification of a phytoplasma infecting grapevine in the Republic of Macedonia. Vitis, 42: 181-185. 


\title{
ИСПИТУВАЊЕ НА ФИТОПЛАЗМАТСКИОТ СТАТУС КАЈ ВИНОВАТА ЛОЗА (CANDIDATUS PHYTOPLASMA SOLANI) ВO РЕПУБЛИКА СЕВЕРНА МАКЕДОНИЈА
}

\author{
Васил Костадиновски ${ }^{1}$, Емилија Арсов ${ }^{2 *}$, Саша Митрев ${ }^{2}$ \\ 'Универзитет "Гоче Делчев" - Штип, Земјоделски факултет, дипломиран земјоделски инженер \\ 2Универзитет „Гоче Делчев" - Штип, Земјоделски факултет, Катедра за заштита на \\ растенијата и животната средина, УНИЛАБ лабораторија, Република Северна Македонија \\ *Corresponding author:emilija.arsov@ugd.edu.mk
}

\section{Резиме}

Фитоплазмите (Candidatus Phytoplasma) се безклеточни форми на бактерии кои не се изолираат на хранлива подлога, и кои се наоѓаат во растителниот флоем и во клетките на инсектите вектори. Економското значење на болестите предизвикани од „жолтилата кај виновата лоза“ Grapevine yellows (GY) е големо насекаде во светот и најчесто распространетите фитоплазми припаѓаат на рибозоналните подгрупи 16SrV-C и -D (етиолошки причинител Flavescence dorée, FD фитоплазмата) и 16SrXII-A (Candidatus Phytoplasma solani, етиолошки причинител Bois noir, BN фитоплазмата). Овие две групи на фитоплазми предизвикуваат слични симптоми, но разликите се забележуваат во епидемиологијата.

Целта на ова истражување беше идентификација и карактеризација на фитоплазмите кои припаѓаат на GY групата („жолтила“) во лозовите насади во нашата земја, со помош на молекуларна анализа на геновите stamp и map. Добиените резултати од истражувањето го докажаа присуството на BN Bois noir, stolbur, економски значајна фитоплазма која предизвикува значителни економски загуби кај грозјето. Од деталните истражувања, преку молекуларна карактеризација на видовите од BN фитоплазмата го потврдивме присуството на три различни stamp генотипови (St1, St30, St37), додека FD фитоплазмата сѐ уште не е потврдена во нашата земја.

Оваа дата база на податоци добиени од нашето истражување може да биде корисна за идни анализи фокусирани на испитување на епидемиологијата на BN и FD.

Клучни зборови: „жолтила кај виновата лоза“, Flavescence doree, Bois Noir, stamp и тар гени 